\title{
TINJAUAN YURIDIS SEJARAH ANTROPOLOGI HUKUM SEBAGAI DASAR ANTROPOLOGI HUKUM
}

\author{
RAUDHATUL ADANI \\ Email : adaniraudhatul@gmail.com \\ 2110003600217 \\ UNIVERSITAS EKASAKTI
}

\section{A. PENDAHULUAN}

Antropologi secara etimologis berasal dari bahasa Yunani. Kata anthropos berarti manusia dan logos berarti ilmu pengetahuan. Jadi antropologi adalah ilmu yang mempelajari manusia. Dalam ilmu antropologi hukum dipelajari mengenai peran, status atau kedudukan,nilai, norma juga kebudayaan. Semua ini sangat erat kaitannya dengan ilmu antropologi hukum. Sebelum berdirinya Komunisme, magistrat-magistrat Tiongkok, misalnya, tidak berurusan dengan menginterpretasi dan menerapkan aturan hukum untuk kasus-kasus konflik yang terjadi, namun menggunakan aturan hukum hanya sebagai pedoman teladan-teladanyang sangat berguna, tetapi tidak harus diteladani dalam kasus konkrit. Dalam antropologi hukum tidak dapat membatasi diri pada isi peraturan-peraturan hukum dan bentuk-bentuk sanksinya, tapi yang perlu diketahui dengan jelas adalah proses pembentukan hukumnya.Antropologi hukum adalah ilmu yang mempelajari tentang manusia dan budayanya khusus dibidang hukum. Kebudayaan hukum yang dimaksud adalah kekuasaan yang digunakan oleh penguasa untuk mengatur masyarakat agar tidak melanggar kaidah-kaidah sosial yang telah ada didalam suatu masyarakat itu sendiri.Hukum dipahami sebagai milik sebuah masyarakat sebagai suatu keseluruhan.Konsekuensi logisnya, suatu masyarakat dianggap hanya memiliki satu sistem hukum saja yang mengendalikan perilaku semua anggotanya. Tanpa sedikit pun menyelidiki kontrol-kontrol sosial yang bekerja pada tingkat sub masyrakat, sub kelompok (misalnya ,perkumpulan, kelompok orang yang hidup serumah, dan kelompok kerabat) telah secara apriori dikecualikan dari kemungkinan mengatur perilaku anggotanya dengan sistem yang diterapkan oleh pemimpin kelompok dalam keputusan-keputusan khusus sistem yang berdasarkan ciri-ciri khas esensinya amat sangat menyerupai hukum pada masyarakat yang meliputi semua kalangan.Hukum juga diartikan sebagai disiplin (sistem ajaran tentang kenyataan) dan ilmu pengetahuan (yakni ilmu hukum). Sebagai ilmu pengetahuan, maka hukum dikatakan mencangkup ilmu tentang kaidah, ilmu tentang pengertian dasar sistem hukum dan ilmu kenyataan (seperti misalnya sosiologi hukum, antropologi hukum, psikologi hukum,perbandingan hukum dan sejarah hukum) Pengertian lain tentang hukum ya itu bahwa hukum di a rtikan sebagai proses pemerintahan. Proses pemerintahan itu mencangkup peraturan, pemerintahan dalam arti sempit, penanggulangan serta peradilan. Hukum diartikan pula sebagai jalinan nilai. Nilai tersebut merupakan konsepsi abstrak di dalam diri manusia mengenai apa yang dianggap baik serta apa yang dianggap buruk. Hukum diartikan sebagai nilai yang merupakan salah satu unsur pandangan manusia mengenai hal-hal yang seharusnya dianuti karena dianggap baik,dan hal-hal yang seharusnya dihindari karena dianggap buruk. 


\section{B. PEMBAHASAN}

\subsection{Pengertian antapologi hukum}

Antropologi hukum adalah kajian antropologis terhadap makna sosial dari dan pentingnya hukum dengan menelaah bagaimana hukum dibuat termasuk bagaimana konteks sosial pembuatan hukum tersebut, bagaimana hukum mempertahankan dan mengubah institusi sosial lainnya, dan bagaimana hukum membangun perilaku sosial.] Namun seiring perkembangan zaman dan tatanan politik dunia pasca-Perang Dingin, cakupan kajian antropologi hukum meluas di antaranya membahas keterkaitan antara konflik sosial dengan kesenjangan ekonomi dan batasan-batasan hukum dalam melakukan rekayasa sosial. Antropologi hukum kini turut mengkaji hubungan antara politik dan hukum yang juga berubah dalam konteks pascaPerang Dingin tersebut. Sebagai akibat dari perluasan cakupan tersebut, bahkan ada kalangan yang menyebut kajian antropologi hukum pada abad ke-19 sebagai kajian antropologi protolega Pengertian lain tent ang hukum ya itu bahwa hukum di a rtikan s ebaga i pros e spemerintahan. Proses pemerintahan itu mencangkup peraturan, pemerintahan dalam artisempit, penanggulangan serta peradilan. Hukum diartikan pula sebagai jalinan nilai. Nilaitersebut merupakan konsepsi abstrak di dalam diri manusia mengenai apa yang dianggap baikserta apa yang dianggap buruk. Hukum diartikan sebagai nilai yang merupakan salah satuunsur pandangan manusia mengenai hal-hal yang seharusnya dianuti karena dianggap baik,dan hal-hal yang seharusnya dihindari karena dianggap buruk

\subsection{Pembagian Antropologi hukum}

Antropologi mempelajari perkembangan kehidupan manusia dan budayanya, dengan cabang-cabang ilmu, diantaranya; ilmu PraSejarah untuk mempelajari kehidupan asal usul manusia, dan untuk mengetahui ragam bahasa manusia maka harus mempelajari Etnolinguistik, sedangkan ilmu yang mempelajari cara manusia berbangsa dan berbudaya disebut Etnologi. Antropologi adalah studi ilmu yang mempelajari tentang manusia dari Aspek Budaya, Perilaku, Nilai, Keanekaragaman, dan lainnya. Antropologi terbagi dalam: Antropologi Ekonomi, Antropologi Politik, Antropologi Pendidikan, dan Antropologi Hukum. Antropologi Hukum merupakan ilmu yg mempelajari manusia dengan kebudayaan, khususnya di bidang Hukum, atau ilmu tentang Manusia dalam kaitannya dengan Kaidah-kaidah sosial yang bersifat Hukum.

\subsection{Hubungan Budaya Dan Kebudayaan Hukum}

Hukum sangat berkaitan erat dengan kebudayaan. Hukum sendiri merupakan produk kebudayaan, karena sejatinya produk hukum adalah produk ciptaan manusia. Dalam studi hukum dikenal struktur hukum, substansi hukum, dan budaya hukum. Hukum diciptakan memiliki karakteristik yang berbeda-beda dari satu daerah ke daerah lainnya sesuai dengan kebudayaan setempat. Artinya, kebudayaan membentuk hukum. Menurut Prof. Tjip, hukum itu bukanlah skema yang final[3], tetapi terus bergerak sesuai dengan dinamika dan perkembangan zaman umat manusia. Artinya, hukum akan terus berubah sesuai dengan perkembangan zaman dan dinamika manusia ini terlahir dalam proses kebudayaan yang berbeda. Kebudayaan yang terdapat dalam masyarakat terlibat dalam hal pembentukan hukum. Di Indonesia dikenal adanya masyarakat Hukum Adat yang jumlahnya sangat banyak. Perkembangan kebudayaan dan hukum menciptakan suatu subjek hukum yang bernama Hukum Adat. Dalam Pendidikan Tinggi hukum, terdapat mata kuliah yang kaitannya dengan Hukum, Masyarakat, dan Kebudayaan: Hukum Adat, Antropologi Hukum, Hukum dan Masyarakat, dan Sosiologi Hukum. Mata kuliahmata 
kuliah inilah adalah awal pengenalan mahasiswa hukum terhadap hubungan dari hukum dan kebudayaan. Bahwa kebudayaan memiliki peran penting terhadap eksistensi hukum. Dimensi kebudayaan ini masuk kedalam norma-norma hukum. Hal ini terjadi dengan adanya Hukum Adat yang lebih sempit lagi melahirkan konsep-konsep hak tanah atas masyarakat adat yang lebih sering dikenal sebagai hak ulayat. Kebudayaan juga memberi ruang dalam proses penyelesaian perkara secara informal, seperti yang terjadi dalam masyarakat Kpelle di Liberia Tengah, Afrika. Kebudayaan hadir dimana-dimana, dan membentuk sebuah pemahaman hukum yang sifatnya pluralis

\subsection{Arena kajian Antropologi hukum Kajian Antropologi}

Hukum adalah menggali norma dan nilai-nilai dalam masyarakat. Arena Antropologi Hukum mempelajari manusia dan budaya hukum, karenanya kaidah sosial yang tidak bersifat hukum bukanlah sasaran pokok penelitian Antropologi Hukum. Norma / kaidah menurut Antropologi Hukum pola ulangan perilaku dalam masyarakat. Norma / Kaidah adalah nilai dasar yang ada dalam masyarakat yang dapat mengukur perilaku manusia agar dapat menilai mana perbuatan benar dan mana yang tidak benar. Norma memiliki aspek hukum ketika aparat menjatuhkan sanksi karena ada perbuatan yang menyimpang atau melanggar hukum. Sanksi bersifat positif seperti dengan membayar denda atau kerja sosial, dan sanksi bersifat negatif seperti hukuman badan atau dikucilkan.. Hukum muncul dari peradaban manusia, dimana ada 2 orang atau lebih di situ ada hukum.

\subsection{Sifat keilmuan antropologi hukum}

1. Antropologi Hukum tidak membatasi pandangan pada kebudayaan tertentu (studi perbandingan).

2. Antroplogi Hukum, mempelajari masyarakat sebagai suatu keseluruhan yang utuh, dimana bagian-bagiannya saling bertautan.

3. Antropologi Hukum Modern tidak memusatkan perhatian hanya pada kekuatan sosial dan hal superorganis.

4. Antropologi Hukum memandang masyarakat secara Dinamis, sehingga peranan sosial dan Hukum tidak terbatas mempertahankan status quo.

5. Antropologi Hukum termasuk ilmu Hukum yang empiris.

\subsection{Ruang Lingkup Antropologi Hukum}

Ruang Lingkup Antropologi Hukum adalah suatu spesialisasi dari Antropologi Budaya, Antropologi Sosial, dan Kebudayaan Hukum yang menyangkut Aspek - aspek Hukum. Laura Nader dalam bukunya "The Anthropological Study of Law “ ( 1965 ), mengemukakan masalah pokok yang merupakan ruang lingkup Antropologi Hukum sebagai berikut:

1. Apakah dalam setiap masyarakat terdapat Hukum dan bagaimana karateristik Hukum yg Universal?

2. Bagaimana Hubungan antara Hukum dengan aspek kebudayaan dan organisasi sosial?

3. Apakah mungkin diadakan Tipologi Hukum tertentu sedangkan variasi karakteristik hukum terbatas?

4. Apakah Tipologi Hukum berguna untuk menelaah hubungan antara Hukum dengan Aspek Budaya dan organisasi sosial, dan

5. Mengapa Hukum itu berubah, setrta bagaimana cara mendeskripsikan Sistemsistem Hukum? 
2.7 kajian antropologi hukum dengan ilmu sosial lainya

Di dalam perkembangan antropologi, masalah hukum sebenarnya juga sudah pernah ditelaah, walaupun di dalam suatu kerangka kebudayaan yang serba luas. Sarjana-sarjana antropologi seperti Barton, Radcliffe-Brown, Malinowski dan lainnya, pernah memusatkan perhatian pada hukum sebagai suatu gejala sosial-budaya. Menurut Ihromi (1986; 3) relevansi menelaah hukum dari segi antropologi, antara lain adalah:

(a). Berkenaan dengan masalah yang dihadapi oleh negara-negara berkembang (tentunya termasuk Indonesia) yang secara budaya bersifat pluralistis dalam cita-citanya mewujudkan unifikasi hukum atau modernisasi hokum;

(b). berkenaan dengan kemungkinan munculnya masalah bila warga masyarakat dari lingkungan sukubangsa tertentu masih mempunyai norma-norma tradisional yang kuat dan menuntut ketaatan mengenai hal-hal tertentu, sedangkan dalam norma hukum yang sudah tertulis dan berlaku secara nasional, hal- hal yang harus ditaati itu justru dirumuskan sebagai hal yang terlarang. Secara faktual, masalah-masalah yang dirumuskan ke dalam dua point utama itu sudah terjadi, baik berkenaan dengan munculnya konflik horisontal di pelbagai wilayah, pertikaian antara state (maupun pemda) dengan masyarakat, maupun antar kelompok masyarakat sendiri. Hukum, menurut Benda-Beckmann $(1979 ; 113-114)$ adalah suatu cara khusus untuk membatasi otonomi anggota-anggota masyarakat. Kebanyakan penulis menyetujui bahwa hukum adalah suatu bentuk pengawasan sosial, itulah mengapa secara esensial sifatnya normatif, dan hal itu merujuk pada apa yang disebut (sebagai) konsepsi- konsepsi yang obyektif. Implikasi pendekatan semacam ini adalah: bahwa hukum memberi input kepada pranata pengendalian sosial (apapun variant-nya) dan kemudian kepada rujukan berpikir masyarakat, dan sebaliknya. Hukum, di sisi lain, dapat pula menyebabkan perubahan perangkat berpikir, dan rujukan kemasyarakatan lainnya atau dikenal dalam sosiologi hukum sebagai "law as tool of social engineering". Namun, bila kesemua hal itu berubah (dan pada kenyataannya memang selalu demikian), maka hukum pun berubah mengikuti perubahan masyarakat danlingkungannya. bidang ilmu lainnya, seperti dengan ilmu administrasi, Ilmu Politik, Ilmu Sejarah, dan sebagainya.

\subsection{Sejarah Antropologi Hukum}

Antropologi hukum merupakan salah bidang ilmu hukum yang masih sangat jarang diketahui oleh masyarakat luas. Orang lebih mengenal antropologi sebagai bidang ilmu yang dekat dengan peristiwa sejarah dan budaya dan karena itu tidak mungkin memiliki kaitan dengan ilmu hukum. Namun inilah hukum, bidang ilmu yang sangat luas dan mencakup hampir seluruh aspek kehidupan manusia. Awal 1970-an dapat dicatat sebagai formulasi dari perkembangan pendidikan ilmu hukum empiris dengan menggunakan pendekatan sosiologis untuk mengkaji fenomenafenomena hukum dalam masyarakat sedang berkembang di Indonesia, yang dikenal kemudian sebagai disiplin sosiologihukum (sociology of law). Nama-nama akademisi hukum seperti Soerjono Soekanto (alm.) dari UI, Satjipto Rahardjo dari UNDIP, dan Sutandyo Wignyosubroto dari UNAIR dapat dicatat sebagai para perintis pengenalan mata kuliah sosiologi hukum di fakultas-fakultas hukum di Jawa. Kemudian, sejak warsa 1980-an dunia pendidikan ilmu hukum di Indonesia semakin diperkaya dengan pengenalan studi-studi hukum empiris dengan menggunakan pendekatan antropologis. Untuk ini, T.O. Ihromi dan Valerine J.L. Kriekhoff dari UI bekerjasama dengan F. von Benda-Beckmann dari Wageningen Agriculture University the Netherlands dapat dinobatkan sebagai peletak dasar studistudi antropologis tentang hukum yang kemudian dikenal sebagai antropologihukum (anthropology of law,legal 
anthropology, anthropological study of law). Makalah bersahaja ini mencoba untuk memberi pemahaman mengenai antropologi hukum sebagai bidang studi ilmu hukum empiris, dengan berfokus pada awal pemikiran studi-studi antropologis tentang hukum, pengembangan konsep hukum dalam studi antropologi hukum, perkembangan tematema kajian antropologi hukum, metodologi antropologi hukum, dan diskusi tema kemajemukan hukum dalam studi antropologi hukum. Dari optik ilmu hukum, antropologi hukum pada dasarnya adalah sub disiplin ilmu hukum empiris yang memusatkan perhatiannya pada studi-studi hukum dengan menggunakan pendekatan antropologis. Kendati demikian, dari sudut pandang antropologi, sub disiplin antropologi budaya yang memfokuskan kajiannya pada fenomena empiris kehidupan hukum dalam masyarakatsecara luas dikenal sebagai antropologi hukum. Antropologi hukum pada dasarnya mempelajari hubungan timbalbalik antara hukum dengan fenomena-fenomena sosial secara empiris dalam kehidupan masyarakat; bagaimana hukum berfungsi dalam kehidupan masyarakat, atau bagaimana hukum bekerja sebagai alat pengendalian sosial (social control) atau sarana untuk menjaga keteraturan sosial (social order) dalam masyarakat. Dengan kata lain, studi-studi antropologis mengenai hukum memberi perhatianpada segi-segi kebudayaan manusia yang berkaitan dengan fenomena hukum dalam fungsinya sebagai sarana menjaga keteraturan sosial atau alat pengendalian sosial (Pospisil, 1971:x, 1973:538; Ihromi, 1989:8). Karena itu, studi antropologis mengenai hukum secara khusus mempelajari prosesproses sosial di mana pengaturan mengenai hak dan kewajiban warga masyarakat diciptakan, dirobah, dimanipulasi, diinterpretasi, dan diimplementasikan oleh warga masyarakat (F. von Benda-Beckmann, 1979, 1986). Awal pemikiran antropologis tentang hukum dimulai dengan studi-studi yang dilakukan oleh kalangan ahli antropologi dan bukan dari kalangan sarjana hukum. Awal kelahiran antropologi hukum biasanya dikaitkan dengan karya klasik Sir Henry Maine yang bertajuk The Ancient Law yang diterbitkan pertama kali pada tahun 1861. Ia dipandang sebagai peletak dasar studi antropologis tentang hukum melalui introduksi teori evolusionistik (the evolusionistic theory) mengenai masyarakat dan hukum, yang secara ringkas menyatakan: hukum berkembang seiring dan sejalan dengan perkembangan masyarakat, dari masyarakat yang sederhana (primitive), tradisional, dan kesukuan (tribal) ke masyarakat yang kompleks dan modern, dan hukum yang inherent dengan masyarakat semula menekankan pada status kemudian wujudnya berkembang ke bentuk kontrak (Nader, 1965; Roberts, 1979; Krygier, 1980; Snyder, 1981). Tema kajian pada fase awal studi-studi teoritis mengenai hukum dengan pendekatan antropologis lebih difokuskan pada fenomena hukum dalam masyarakat bersahaja (primitive), tradisional (traditional), dan kesukuan (tribal) dalam skala evolusi bentuk-bentuk organisasi sosial dan hukum yang mengiringi perkembangan masyarakat manusia. Sedangkan, metode kajian yang digunakan untuk memahami fenomena hukum dalam masyarakat adalah apa yang dikenal sebagai armchair methodology, yaitu metodologi untuk memahami hukum dalam perkembangan masyarakat melalui kajian-kajian yang dilakukan di belakang meja, sambil duduk di kursi empuk, dalam ruangan yang nyaman, dengan membaca dan menganalisis sebanyak mungkin documentary data yang bersumber dari catatancatatan perjalanan para petualang atau pelancong, dari laporan-laporan berkala dan dokumen resmi para missionaris, pegawai sipil maupun para serdadu pemerintah kolonial dari daerah-daerah jajahannya (F. von BendaBeckmann, 1989). Pada awal abad ke-20 metode kajian hukum dari belakang meja mulai ditinggalkan, dan mulai memasuki perkembangan metode studi lapangan (fieldwork methodology) dalam studi-studi antropologis tentang hukum. Karya Barton, misalnya, yang berjudul Ifugao Law yang dipublikasikan pertama kali pada tahun 1919 merupakan hasil dari fieldwork yang intensif dalam masyarakat suku Ifugao di Pulau Luzon Philipina. Kemudian, muncul karya Malinowski 
berjudul Crime and Custom in Savage Society yang pertama kali dipublikasikan pada tahun 1926 adalah hasil studi lapangan yang komprehensif dalam masyarakat suku Trobrian di kawasan Lautan Pasific, dan seterusnya sampai sekarang metode fieldwork menjadi metode khas dalam studi-studi antropologi hukum. Tema-tema kajian yang dominan pada fase awal perkembangan antropologi hukum berkisar pada pertanyaan-pertanyaan : apakah hukum itu ? apakah ada hukum dalam masyarakat yang bersahaja, tradisional, dan kesukuan ?; bagaimanakah hukum berujud dan beroperasi dalam kehidupan masyarakat ? Pada dekade tahun 1940-an sampai 1950-an tematema kajian antropologi hukum mulai bergeser ke mekanisme-mekanisme penyelesaian sengketa dalam masyarakat sederhana. Karya klasik dari Llewellyn dan Hoebel bertajuk The Cheyenne Way (1941) merupakan hasil studi lapangan kolaborasi dari seorang sarjana hukum dengan ahli antropologi dalam masyarakat suku Cheyenne (suku Indian) di Amerika Serikat. Kemudian, Hoebel mempublikasikan The Law of Primitive Man (1954), disusul dengan karya Gluckman mengenai hukum orang Barotse dan Lozi di Afrika, karya Bohannan mengenai hukum orang Tiv, karya Gulliver mengenai hukum orang Arusha dan Ndendeuli. Karya Fallers mengenai hukum dalam masyarakat suku Soga, dan karya Pospisil tentang hukum orang Kapauku di Papua. Fase perkembangan tema studi antropologi hukum ke arah mekanisme-mekanisme peneyelesaian sengketa seperti disebutkan di atas disebut oleh F. von Benda-Beckmann (1989) sebagai fase the anthropology of dispute settlements. Pada dekade tahun 1960-an tema studistudi antropologi lebih memberi perhatian pada fenomena kemajemukan hukum atau pluralisme hukum. Tema pluralisme hukum pertama-tama difokuskan pada kemajemukan cara-cara penyelesaian melalui mekanisme tradisional, tetapi kemudian diarahkan kepada mekanisme dan institusi penyelesaian sengketa menurut hukum pemerintahkolonial dan pemerintah negaranegara yang sudah merdeka. Karya Bohannan, Gluckman, dan Gulliver misalnya, tidak secara sistematis memberi perhatian pada eksistensi mekanisme dan institusi penyelesaian sengketa menurut hukum kolonial dan hukum negara-negara sedang berkembang. Sejak tahun 1970-an tema studi-studi antropologi hukum secara sistematis difokuskan pada hubungan antar institusiinstitusi penyelesaian sengketa secara tradisional, neo-tradisional, dan menurut institusi hukum negara. Karya Nader dan Todd (1978) misalnya, memfokuskan kajiannya pada proses, mekanisme, dan institusi-institusi penyelesaian sengketa di komunitas masyarakattradisional dan modern di beberapa negara di dunia, melalui Berkeley Village Law Projects, menjadi karya yang memperlihatkan kecenderungan baru dari topik-topik studi antropologi hukum. Publikasi lain yang perlu dicatat adalah mekanisme penyelesaian sengketa di kalangan orang Togo di Afrika karya van Rouveroy van Nieuwaal, kemudian karya F. von BendaBeckmann (1979) dan K. von Benda-Beckmann (1984) yang memberi pemahaman tentang penyelesaian sengketa harta warisan di kalangan orang Minangkabau menurut pengadilan adat dan di pengadilan negeri di Sumatera Barat. Fase selanjutnya studi pluralisme mekanisme penyelesaian sengketa mulai ditinggalkan, dan mulai diarahkan kepada studi-studi pluralisme hukum di luar penyelesaian sengketa. Karya Sally F. Moore (1978) misalnya, mengenai kemajemukan hukum agraris dalam kehidupan suku Kilimanjaro di Afrika, dan mekanisme dalam proses produksi pabrik garment terkenal di Amerika dapat dicatat sebagai perkembangan baru studi pluralisme hukum. Kemudian, studi-studi pluralisme hukum mulai difokuskan pada mekanisme jaminan sosial (social security), pasar dan perdagangan, mekanisme irigasi pertanian, institusi koperasi dan perkreditan di daerah pedesaan di negara-negara sedang berkembang. Studi-studi ini dikembangkan oleh Agrarian Law Department Wageningen Agriculture University.

\section{PENUTUP}


Antropologi adalah salah satu cabang ilmu pengetahuan sosial yang mempelajari tentang budaya masyarakat suatu etnis tertentu. Antropologi lahir atau muncul berawal dari ketertarikan orang-orang Eropa yang melihat ciri-ciri fisik, adat istiadat, budaya yang berbeda dari apa yang dikenal di Eropa. Terbentuklah ilmu antropologi dengan melalui beberapa fase. Antropologi lebih memusatkan pada penduduk yang merupakan masyarakat tunggal, tunggal dalam arti kesatuan masyarakat yang tinggal daerah yang sama, antropologi mirip seperti sosiologi tetapi pada sosiologi lebih menitik beratkan pada masyarakat dan kehidupan sosialnya. Perkembangan antropologi terdiri atas 4 tahap yaitu ; 1) Fase Pertama (Sebelum tahun 1800-an) Sekitar abad ke15-16, bangsa-bangsa di Eropa mulai berlomba-lomba untuk menjelajahi dunia. Mulai dari Afrika, Amerika, Asia, hingga ke Australia. Dalam penjelajahannya mereka banyak menemukan hal-hal baru. Mereka juga banyak menjumpai suku-suku yang asing bagi mereka. Kisah-kisah petualangan dan penemuan mereka kemudian mereka catat di buku harian ataupun jurnal perjalanan. Fase Kedua (tahun 1800-an) Pada fase ini, bahan-bahan etnografi tersebut telah disusun menjadi karangankarangan berdasarkan cara berpikir evolusi masyarakat pada saat itu. masyarakat dan kebudayaan berevolusi secara perlahan-lahan dan dalam jangka waktu yang lama. Mereka menganggap bangsa-bangsa selain Eropa sebagai bangsa-bangsa primitif yang tertinggal, dan menganggap Eropa sebagai bangsa yang tinggi kebudayaannya Fase Ketiga (awal abad ke-20) Pada fase ini, negara-negara di Eropa berlomba-lomba membangun koloni di benua lain seperti Asia, Amerika, Australia dan Afrika. Dalam rangka membangun kolonikoloni tersebut, muncul berbagai kendala seperti serangan dari bangsa asli, pemberontakanpemberontakan, cuaca yang kurang cocok bagi bangsa Eropa serta hambatan-hambatan lain. Fase Keempat (setelah tahun 1930-an) Pada fase ini, Antropologi berkembang secara pesat. Kebudayaan-kebudayaan suku bangsa asli yang dijajah bangsa Eropa, mulai hilang akibat terpengaruh kebudayaan bangsa Eropa.

Antropologi sangat besar peranannya dalam perkembangan kehidupan manusia sehingga diharapkan kepada kita semua untuk selalu mengembangkan wawasan dan memperdalam pemahaman tentang kehidupan masyarakat yang berkaitan dengan antropologi.

\section{DAFTAR PUSTAKA}


Darmini Roza dan Laurensius Arliman S, Peran Pemerintah Daerah Di Dalam Melindungi Hak Anak Di Indonesia, Masalah-Masalah Hukum, Volume 47, Nomor 1, 2018. https://doi.org/10.14710/mmh.47.1.2018.10-21

Laurensius Arliman S, Peranan Metodologi Penelitian Hukum di Dalam Perkembangan Ilmu Hukum di Indonesia, Soumatera Law Review, Volume 1, Nomor 1, 201. http://doi.org/10.22216/soumlaw.v1i1.3346.

Laurensius Arliman S, Peran Badan Permusyawaratan Desa di Dalam Pembangunan Desa dan Pengawasan Keuangan Desa, Padjadjaran Journal of Law, Volume 4, Nomor 3, 2017. https://doi.org/10.15408/jch.v4i2.3433.

Laurensius Arliman S, Penanaman Modal Asing Di Sumatera Barat Berdasarkan UndangUndang Nomor 25 Tahun 2007 Tentang Penanaman Modal, Supremasi Hukum, Volume 1, Nomor 1, 2018. http://dx.doi.org/10.36441/hukum.vli01.102 .

Laurensius Arliman S, Memperkuat Kearifan Lokal Untuk Menangkal Intoleransi Umat Beragama Di Indonesia, Ensiklopedia of Journal, Volume 1, Nomor 1, 2018, https://doi.org/10.33559/eoj.v1i1.18.

Laurensius Arliman S, Perkawinan Antar Negara Di Indonesia Berdasarkan Hukum Perdata Internasional, Kertha Patrika, Volume 39, Nomor 3, 2017, https://doi.org/10.24843/KP.2017.v39.i03.p03.

Laurensius Arliman S, Partisipasi Masyarakat Di Dalam Pengelolaan Uang Desa PascaUndangUndang Nomor 6 Tahun 2014 Tentang Desa, Jurnal Arena Hukum, Volume 12, Nomor 2, 2019, https://doi.org/10.21776/ub.arenahukum.2019.01202.5.

Laurensius Arliman S, Mewujudkan Penegakan Hukum Yang Baik Di Negara Hukum Indonesia, Dialogica Jurnalica, Volume 11, Nomor 1, 2019, https://doi.org/10.28932/di.v11i1.1831.

Laurensius Arliman S, Mediasi Melalui Pendekatan Mufakat Sebagai Lembaga Alternatif Penyelesaian Sengketa Untuk Mendukung Pembangunan Ekonomi Nasional, UIR Law Review, Volume 2, Nomor 2, 2018, https://doi.org/10.25299/uirlrev.2018.vol2(02).1587

Laurensius Arliman S, Peranan Filsafat Hukum Dalam Perlindungan Hak Anak Yang Berkelanjutan Sebagai Bagian Dari Hak Asasi Manusia, Doctrinal, Volume 1, Nomor 2,2016.

Laurensius Arliman S, Ni Putu Eka Dewi, Protection of Children and Women's Rights in Indonesiathrough International Regulation Ratification, Journal of Innovation, Creativity and Change Volume 15, Nomor 6, 2021.

Laurensius Arliman S, Gagalnya Perlindungan Anak Sebagai Salah Satu Bagian Dari Hak Asasi Manusia Oleh Orang Tua Ditinjau Dari Mazhab Utilitarianisme, Jurnal Yuridis, Volume 3, Nomor 2, 2016, http://dx.doi.org/10.35586/.v3i2.180.

Laurensius Arliman S, Tantangan Pendidikan Kewarganegaraan Pada Revolusi 4.0, Jurnal Ensiklopedia Sosial Review, Volume 2, Nomor 3, $2020 .$. 
